\title{
TRAUMA HEALING BAGI MASYARAKAT TERDAMPAK GEMPA DESA GUMANTAR KECAMATAN KAYANGAN LOMBOK UTARA
}

\author{
Subhan Abdullah Acim \& Muhammad Sa'í \\ Universitas Islam Negeri Mataram \\ muhammadsai@uinmataram.ac.id
}

\begin{abstract}
Abstrak: Gempa Lombok yang terjadi pada bulan Agustus 2018 menimbulkan banyak korban jiwa dan kerugian materi terutama bagi warga kabupaten Lombok Utara. Pasca gempa, sebagian dari korban yang selamat dan luka mengalami trauma sehingga terganggu kondisi mental dan psikologisnya. Kondisi ini membutuhkan penanganan sehingga dapat memulihkan kondisi mental para korban gempa. Kegiatan pengabdian ini bertujuan untuk memulihkan kondisi mental dan psikologis masyarakat Lombok pasca gempa. Kegiatan pengabdian dilakukan melalui trauma healing dengan pendekatan dakwah Islam terhadap masyarakat korban gempa. Peserta kegiatan ini adalah sebanyak 60 orang yang tinggal di Desa Gumantar, Kecamatan Kayangan, Kabupaten Lombok Utara yang terdampak gempa. Hasil kegiatan menunjukkan bahwa program trauma healing dengan pendekatan dakwah Islam mampu meningkatkan kesadaran pengamalan agama yang baik sehingga memiliki semangat untuk bangkit kembali dalam menjalani kehidupannya.
\end{abstract}

Kata Kunci: korban gempa, trauma healing, mental, psikologi

\begin{abstract}
The earthquakes that hit Lombok on August 2018 caused many casualties and material losses, especially for residents of North Lombok district. After the earthquakes, some of the survivors and injuries were trauma so that their mental and psychological conditions were disturbed. This condition certainly requires treatment which can restore the mental condition of the earthquake victims. This community service program aims to restore the mental and psychological conditions of the people of Lombok after the earthquake. The program was carried out through trauma healing with an Islamic da'wa approach to earthquake victims. The participants were sixty residents of Gumantar Village, Kayangan Sub-District, North Lombok. The results of the activity showed that the trauma healing program with the Islamic da'wa approach was able to increase awareness of good religious practices so that they had the spirit to live their lives again.
\end{abstract}

Keywords: earthquake victims, trauma healing, mentality, psychology

\section{Pendahuluan}

Desa Gumantar merupakan salah satu dari 8 Desa yang berada di Kecamatan Kayangan Kabupaten Lombok Utara. Desa dengan luas kurang lebih 3.800 hektar adalah hamparan anugrah Ilahi yang luar biasa. Desa ini memiliki daya tarik dan atau potensi yang sangat besar, baik secara fisik maupun non fisik. Secara fisik seperti tergambar dalam profil desa, memiliki panorama yang indah akan juga memiliki warisan budaya yang asli dan unik yaitu; 1) adanya Dasan Bele'yaitu pemukiman asli yang menjadi cagar budaya yang tetap dipertahankan, 2) adanya Masjid Kuno yang terletak di Dusun Gumantar. Masjid ini merupakan salah satu dari 5 Masjid Kuno yang terdapat di Lombok Utara. Masjid Kuno Desan Gumantar telah dijadikan sebagai situs peninggalan sejarah, 3) adanya hutan adat yang dikuasi dan dikelola oleh masyarakat secara mandiri dan berada di bawah pengawasan adat. Hutan adat desa Gumantar seluas 9,5 hektar ini terjaga dengan ketat. Di wilayah kawasan hutan ini masyarakat bisa memelihara sapi ternak mereka, atau mencari kayu-kayu kering yang dijadikan untuk memasak. 
Di hutan yang teduh ini terdapat pohon-pohon besar menjulang tinggi dan banyak juga terdapat binatang-binatang hutan seperti monyet dan burung-burung, dan 4) adnya sumber mata air (air terjun). Air terjun yang menjadi daya tarik alamiah Desa Gumantar terletak berdekatan dengan hutan rakyat (hutan adat). Selain kekuatan fisik di atas Desa Gumantar juga memiliki kekuatan non fisik yaitu system adat istiadat yang sangat kuat. System sosial merupakan pranata sosial masyarakat yang menjadi bagian terintegral dengan seluruh aktivitas sosial. Dengan awiqawiq (aturan yang disepakati bersama) mesyarakat menjalin hubungan sosial secara damai. Mereka sangat menghormati aturan-atauran yang menjadi kesepakatan mereka.

Namun demikian guncangan keras (force majeure) berupa gempa yang melanda pulau Lombok, khususnya daerah Lombok Utara dengan falsafahnya Tioq, Tata, Tunaq (berarti tumbuh, teratur, menyayangi sebagi symbol kesejahteraan dan keadilan) telah membekas sangat besar pada hati masyarakat. Bagi masyarakat desa Gemantar Lombok Utara peristiwa yang terjadi secara terus menerus telah membawa kerugian yang tidak sedikit. Kejadian tersebut selain menelan banyak korban jiwa, juga telah meluluhlantahkan berbagai bangunan; rumahrumah masyarakat, masjid, perkatoran dan juga pertokoan dan sebaginya. Tidak kurang dari 48 orang meninggal, 1050 orang luka-luka, dan bahkan lebih dari 90 persen rumah dan bangunan rusak. ${ }^{1}$ Selain kerusakan-kerusakan akses transportasi dan ruas-ruas jalan yang menjadi penghubung satu kampong atau dusun dengan lainnya, demikian halnya perekonomian masyarakat menjadi lumpuh. ${ }^{2}$

Akibat dari kejadian besar dan terus-menerus ini, masyarakat Desa Gumantar Kecamatan Kayangan Lombok Utara mengalami persoalan dan kesulitan hidup mulai dari masalah tempat tinggal, kekurangan makanan dan air bersih hingga ketakutan dan trauma yang sangat besar dan mengahantui mereka, keputusasaan, dan meratapi keadaan yang dialami. Berbagai persoalan tersebut perlu penanganan secara tepat terutama mengatasi berbagai masalah psikis yang berkepanjangan atau yang disebut trauma akibat gempa tersebut. Trauma Healing ${ }^{3}$ dapat jadikan sebagai salah satu metode dan atau cara yang dianggap paling tepat dalam uapaya penyembuhan pada gangguan psikologis yang dialami oleh seseorang karena lemahnya ketahanan fungsi-fungsi mental.

\footnotetext{
${ }^{1}$ Sumber data berdasarkan hasil observasi dan wawancara dengan kepala Desa Gumantar bapak Jupati pada tanggal 1 September 2018

2 Berdasarkan survey lapangan yang dilakukan oleh pengabdi situs religious-sosial beruapa Masjid Kuno yang terletak di Desa Gumantar masih berdiri kokoh demikian juga pemukiman adat yang terletak di Dasan Sebele' tetap berdiri tegak. Masjid Kuno Desa Gumantar yang didirikan sekitar abadke XVI-an merupakan bangunan persegi empat dengan berlantaikan tanah dan berdinding pagar bambu serta beratapkan ilalang. Demikian juga pemukiman adat yang terletak sekitar $3 \mathrm{~km}$ dari kantor desa Gumantar merupakan gugusan bangunan kuno yang berlantaikan tanah, berdinding pagar anyaman bambu dan beratapkan ilalang tetap berdiri. Ditempat ini tersimpan peninggalan naskah kuno berupa mushaf al-Qur'an dan lontar. Kedua situs peninggalan bersejarah ini menjadi lambang religiusitas masyarakat dan berpengaruh besar terhadap pengelolaan kehidupan dan anugrah alam.

${ }^{3}$ Kata trauma healing terdiri dari dua suku kata, yaitu trauma didefinisikan sebagai keadaan jiwa atau tingkah laku yang tidak normal sebagai akibat dari tekanan jiwa atau cedera jasmani, dan healing secara bahasa memiliki arti penyembuhan. Dari definisi di atas, dapat dijelaskan bahwa trauma healing adalah aktivitas atau tindakan yang dilakukan untuk mengurangi dan atau menghilangkan gangguan dalam jiwanya yang disebabkan oleh adanya syok atau trauma.(lihat TIM Penyusun Kamus, Kamus Besar Bahasa Indonesia Departemen Pendidikan dan Kebudayaan cet. Ke X ( Jakarta : Balai Pustaka, 1999 hlm. 1071). Trauma healing merupakan metode penyembuhan pada gangguan psikologis yang dialami oleh seseorang karena lemahnya ketahanan fungsi-fungsi mental. Individu yang mengalami trauma pasca bencana membutuhkan penanganan agar korban tidak terpuruk lebih mendalam akibat kerugian material atau mental.
} 
Secara umum pasca gempa yang menimpa pulau Lombok dan khususnya masyarakat yang tinggal di Desa Gumantar, sedang mengahadapi berbagai permasalahan, antara lain; 1) Masyarakat Desa Gumantar kehilangan tenpat tinggal dan bahkan beberapa orang diantara mereka kehilangan anggota keluarga, 2) Masyarakat Desa Gumantar kehiangan sumber ekonomi dan pendapatan serta sarana dan prasarana umum, 3) Masyarakat Desa Gumantar kehilangan akses dan pelayanan public, 4) Masyarakat Desa Gumantar merasakan ketakutan, kekhawatiran dan bahkan keputuasaan yang tinggi terlebih dengan seringnya terjadi guncangan (gempa bumi), 5) Masyarakat mengalami tekanan dan gangguan pemikiran dan jiwa yeng menyebabkan mereka terpuruk dan tidak mampu untuk bangkit kembali. Kaitannya dengan problem fisik dan psikis masyarakat Desa Gumantar maka pertanyaan inti dalam masalah ini adalah "bagaimana pola pemulihan semangat atau psikis masyarakat pasca gempa atau dengan pertanyaan lain yang lebih aperasional " bagaimana melakukan trauma healing terhadap masyarakat terdampak gempa di Desa Gumantar Lombok Utara?"

Adapun tujuan dari kegiatan pendampingan ini adalah untuk menguatkan semangat dan kesadaran masyarakat dalam mengatasi trauma pasca gempa yang menimpa mereka khususnya masyarakat Desa Gumenter Kecamatan Kayangan Lombok Utara. Dengan demikian manfaat yang diharapkan adalah munculnya kembali semangat baru masyarakat Desa Gumantar Kecamatan Kayangan Lombok Utara dalam mengahadapi dan atau menyikapi gempa bumi menimpa mereka. Sehingga dari kagiatan ini akan muncul kondisi dampingan yang diharapkan, yaitu; 1) terciptanya ketenangan hati dan pikiran masyarakat dalam mengahadapi bala bencana yang menimpa mereka, 2) terwujudnya kesadaran masyarakat tentang pentingnya menumbuhkan kesadaran jiwa dan pikiran, dan 3) adanya kesadaran semua kalangan sehingga terbangun partisipasi mereka dalam mengembangkan semangat gotong royong

\section{Metode}

Pengabdian ini merupakan jenis pengabdian desa binaan model. Model pendampingan dan pemberdayaan masyarakat yang bersifat multidimensi dan integral, sehingga menjadikan objek binaan memiliki keunggulan pada beberapa dimensi dengan memanfaatkan sumberdaya yang dimiliki. ${ }^{4}$ Dan oleh karena persoalan ketakutan, kekhawatiran dan gangguan jiwa lainnya sebagai dampak dari gempa tersebut bersifat multidimensi, maka penanganannya bersifat multi approach (berbagai pendekatan) baik psikis maupun fisik dengan berbagai dimensinya. Kegiatan trauma healing ini pun dilakukann dengan memanfaatkan sumber normative ajaran agama (Islam) dan ilmu jiwa modern.

Adapun pendekatan yang dipergunakan dalam kegiatan ini merupakan partisifatif. ${ }^{5}$ Dalam

\footnotetext{
${ }^{4}$ Pedoman pengbadian dosen Universitas Islam Negeri (UIN) Mataram tahun 2018

${ }^{5}$ Pengabdian dengan pendekatan partisipatif ini memposisikan pengabdi sebagai; a) fasilitator artinya bahwa pengabdi memposisikan dalam proses ini sebagai pembantu masyarakat dalam mendiskusikan dan merefleksikan situasi sosial, mengidentifikasi dan merumuskan isu masalah, mengidentifikasi solusi dan menyusun perencanaan mengatasi masalah, memonitor dan mengevaluasi program aksi,, b) animator artinya bahwa pengabdi membantu masyarakat menemukan dan mendayagunakan potensi sendiri untuk mengatasi masalah yang dihadapi. Termasuk di dalamnya mendorong masyarakat berpikir kritis, kepedulian, berbagi informasi, dan gagasan, c) enabler artinya
} 
pengadian ini pengabdi melibatkan para pihak, yaitu; 1) Universitas Islam Negeri (UIN) Mataram melalui Pusat Pengabdian Kepada Masyarakat (P2M) Lembaga Penelitian, Pengabdian dan Penerbitan (LPPP) sebagai lembaga pendidikan tinggi yang berfungsi sebagai pusat pendidikan dan pengajaran, penelitian dan pengabdian kepada masyarakat (Tridarma Perguruan Tinggi). 2) Pemerintah Desa Gumanter kecamatan Kayangan Lombok Utara sebagai Lembaga Pemerintahan yang besentuhan dan bertanggung jawab secara langsung atas seluruh aktivitas social keagamaan dan pendidikan masyarakat, 3) Kepala dusun se Desa Gumantar yang tetap mengawasai dan berintraksi dengan i setiap kegiatan masyarakat, 4) Tokoh agama, tokoh adat dan tokoh pemuda sebagai pelaku dan sekaligus berinovasi membangun gagasan dan ide secara proaktif-komunikatif

\section{Observasi dan Gali Gagasan}

Tahapan observasi dan gali gagasan ini dilakukan untuk mendapatkan informasi umum tentang kondisi sobjektif dampingan. Adapun hal-hal yang dilakukan pada saat obsevasi ini adalah; pertama, Pengamatan langsung objek untuk melakukan pemetaan/peta konsep yang dapat dijadikan landasan untuk pendampingan dan atau mengakategorisasikan masalah. Kegiatan ini dilakukan oleh oleh pengabdi sebelum pelaksanaan kegiatan dengan datang langsung ke lokasi dan berdiskusi dengan para pihak (kepala desa dan tokoh agama) perihal perubahan tema. Hal ini penting sebab permasalah psikis dihadapai masyarakat Desa Gumantar cukup kompleks, dimana satu persamalahan dengan lain tentu saling terkait dan melengkapi. Kedua, Historical studies (kajian kesejarahan) kajian kesejarahan (historical studies) merupakan langkah pencarian informasi dengan menggali permasalah utama dan harapan masyarakat objek dampingan. Kajian ini penting dilakukan sebab dengan memahami keadaan yang ada dapat membantu pengabdi dalam memetakan muatan-muatan model dan jenis kegiatan.

\section{Desain Model dan Prioritas Dampingan}

Penyusunan model dan atau strategi pendampingan ini dilakukan untuk menyesuaikan jenis, model dan strategi dalam melakukan dampingan sebagaimana termaktub dalam pedoman pelaksanaan. Desain Model dan prioritas dampingan ini disusun sebagai pedoman ( guidenig) pelaksanaan sehingga dapat ditentukan model dan prioritas kegiatan. Desain model dan prioritas kegiatan tersebutkan kemudian dirumuskan menjadi concept note kegiatan yang meliputi; Pertama; aspek daya tarik dan kemanfaatannya bagi komunitas dampingan Kedua; argumen-argumen apa sajakah yang dapat diajukan sebaga alasan memilih komunitas dampingan dan signifikansinya dalam proses pengabdian. Ketiga; apa cara atau langkah secara nyata kondisi komunitas dan atau unitas yang akan didampingi sesuai dengan hasil pengamatan dan atau kegiatan pendahuluan (preliminaryresearch) yang telah dilakukan. Deskripsi perlu disertai data-data kuantitatif maupun kualitatif yang memadai, sehingga tergambar kondisi

\footnotetext{
bahwa pengabdia membantu masyarakat berinisiasi secara bebas dan kreatif untuk mengembangkan diri dalam lingkungannya sebagai bagian dari proses perubahan sosial, serta mengurangi ketergantungan melalui penciptaan kerjasama dan d)catalyst artinya bahwa pengabdi membantu masyarakat mengorganisasikan gagasan dan sumberdayanya dengan kekuatan-kekuatan yang ada di dalam diri mereka
} 
umum dan kondisi spesifik komunitas yang akan menjadi focus dampingan. Keempat, kondisi dampingan yang diharapkan, menjelaskan kondisi yang diharapkan selama dan setelah proses dampingan berlangsung sebagaimana hasil penelitian pendahuluan (preliminaryresearch). Kelima, strategi yang dilakukan untuk mencapai kondisi harapan, menyebutkan sejumlah strategi yang akan dilakukan untuk mencapai kondisi yang diharapkan dan bagaimana kaitannya satu sama lain. Hal ini bisa meliputi metode, teknik, atau kegiatan, yang akan dilakukan agar strategi yang dirancang dapat berjalan. Keenam, pihak-pihak yang terlibat (stakeholders) dan bentuk keterlibatannya.

\section{Hasil dan Pembahasan}

Desa Gumantar salah satu dari 8 desa di Kecamatan Kayangan Kabupaten Lombok Utara. Desa dengan luas 3.800 hektar ini merupakan hamparan lahan perbukitan yang sangat potensial dalam pengembangan tanaman perkebunan seperti kopi, kakau, jambu mente, mangga dan lain-lain. Seperti halnya wilayah-wilayah lain di pulau Lombok, Desa Gumantar mengalami dua musim; kemarau dan penghujan.

Desa Gumantar terdiri dari 16 dusun; Dusun Aik Bari, Dusun Amor-Amor, Dusun Pawang Baturan, Dusun Boyotan Proyek, Dusun Montong Gedeng, Dusun Boyotan Asli, Dusun Boyotan Baru, Dusun Melepah, Dusun Kelanjuh, Dusun Kelanjuh Perigi, Dusun Paok Gading, Dusun Gumantar, Dusun Dasann Terang, Dusun Nangka Lombok, Dusun Tenggorong dan Dusun Dasan Belek. Pada table jumlah penduduk di Kantor Desa Gumantar tercatat sampai dengan bulan Desember 2016 jumlah sebanyak 6.219 jiwa yang terdiri dari 3.122 jiwa laki-laki, dan 3.097 perempuan. Sedangkan jumlah kepala keluarga secara keseluruhan $1.982 .{ }^{6}$ Ditinjau dari sumber perekonomian, masyarakat Desa Gumantar mengandalkan pendapatan perekonomiannya dari sektor pertanian yang terdiri dari tanaman pangan, horticultural dan perkebunan. Sedangkan sektor lainnya adalah sektor pariwisata.

Sebagai bagian dari daerah di kaki gunung rinjani, desa ini bagaikan hamparan anugrah Ilahi yang menyimpan keindahan. Hamparan tanah yang sangat subur, pepohonan yang hijau dan sumber air yang bening menjadi pemandangan indah. Setidaknya ada tiga kekuatan alami yang terjaga dan terpelihara dengan serius, yaitu; pertama, keberadaan Masjid Kuno. Masjid Kuno terletak di Dusun Gumantar. Masjid Gumantar ini diperkirakan dibangun pada abad keXVI bersamaan dengan kedatangan pandakwah Islam. Teori menyebutkan bahwa orang yang membawa Islam masuk ke pulau Lombok adalah Pangeran Songopati dan atau Sunan Prapen. Teori ini dibuktikan dengan adanya kesamaan bahasa atau budaya Lombok dengan Jawa. Misalnya, dua kalimat syahadat yang diartikan dalam bahasa Jawa, sering dipergunakan di dalam upacara pernikahan komunitas Sasak Desa Bayan. ${ }^{7}$

Islam masuk pulau yang dijuluki seribu masjid ini menurut bebarapa teori menyebut bahwa jalur persebarannya melalui utara (Bayan dan sekitarnya termasuk Gumantar) yang

\footnotetext{
${ }^{6}$ Profil Desa Gumantar dikutip 21 Juli 2018 (sebelum terjadinya gempa)

7 Zaki Yamani Athar, Kearifan lokal dalam Ajaran Islam Wetu Telu di Lombok (Mataram: IAIN Ulumuna: vol.IX, edisi 15, 2005), hlm. 71
} 
disebarkan oleh Sunan Giri dari Jawa Tengah. Masjid ini merupakan salah satu dari 5 situs Masjid Kuno yang terdapat di Lombok Utara. Masjid Kuno Desan Gumantar telah dijadikan sebagai situs peninggalan sejarah, kedua, Dasan Bele'. Dasan Bele' (pemukiman besar) adalah pemukiman tradisional penduduk. Di pemukiman ini tata ruang dan atau tata pemukiman penduduk dipertahankan keasliannya. Di Dasan Bele' bentuk dan ataupun penempatan kelengkapan rumah diatur sesuai dengan aturan yang bersifat turun menurun. Setiap rumah ada kamar keluar, ada dapur dan beruga'(bangunan persegi empat yang tiangnya terdiri dari empat atau enam tiang, biasa dijadikan tempat kumpul keluarga). Selain itu di Dasan Bele' ini terdapat juga bangunan tempat kumpul tetua adat (toa' loka) banguan ini hanya dilengkapi pintu kecil (banguna dengan luas kurang lebih 64 mater persegi dengan tinggi pintu kurang lebih tingginya 1 meter dan lebar $80 \mathrm{~cm}$ ). Dasan Bele' ini sekarang menjadi situs wisata andalan di Desa Gumantar. Pada beberapa bagian bangunan para pengunjung tidak boleh memasuki halamannya kecuali dengan menggunkan pakaian adat (tidak diperkenannkan menggunkan celana panjang), ketiga, Hutan Adat. Hutan adat adalah hutan yang dikuasi dan dikelola oleh masyarakat di bawah pengawasan awiq-awiq adat. Hutan rakyat Desa Gumantar seluas 9,5 hektar ini terjaga dengan ketat. Di wilayah kawasan hutan ini masyarakat bisa memelihara dan atau berternak sapi mereka, atau mencari kayu-kayu kering yang dijadikan untuk menanak nasi atau kebutauhan dapur lainnya. Di hutan yang teduh ini terdapat pohon-pohon besar menjulang tinggi dan banyak juga terdapat binatang-binatang hutan seperti monyet dan burung-burung. Keempat. Air Terjun. Salah satu daya tarik alamiah Desa Gumantar ini adalah air terjun.

Masyarakat yang tinggal menetap di Desa Gumantar adalah masyarakat yang sangat kuat mempertahan adat-istiadat dan system social mereka. Hal ini dapat diamati pada dua aspek; pertama, pada aspek tujuan (goal) dari system yang dibangun, dan kedua, aspek pola membangun system social. Pertama , aspek tujuan sosial. Masyarakat Desa Gumantar secara keseluruhan merupakan kelompok masyarakat yang memiliki hubungan kekerabatan dan bersanakkeluargaan. Mereka hidup secara berkelompok dan sangat menjunjung nilai-nilai kekeluargaan dalam berbagai sisi kehidupan mereka baik social keagamaan maupun ekonomi dan bahkan politik. Masyarakat Desa Gumantar sangat menjaga keutuhan kelompok, organisasi social keagamaan dan kerterhubungan antar anggota masyarakat dan dengan tetua adat (toa' loka). ${ }^{8}$ Keterikatan dan kekuatan hubungan antar warga ini terlihat pada kegiatan-kegiatan sosila kemasyarakatan seperti rowah hidup (gawe idup), ${ }^{9}$ rowah mati (gawe mate). ${ }^{10}$ Masyarakat Desa Gumantar seperti tersebut di atas adalah komunitas masyarakat yang secara social berasal dari satu keturuan dan kekerabatan. Maka hubungan antar komunitas tersebut tetap dipertahankan dengan membangun rasa persamaan (dignity) dan juga kepercayaan (trust). Adapun pola-pola perekatan kebersamaan dan kepercyaan antar masyarakat dalam

${ }^{8}$ Wawancara dengan Bpk Ust. M. Basri (Ketua BPD) Desa Gumantar, 9 September 2017 di Kantor Desa Gumantar

9 Mereka melakukan setiap kegiatan secara bersama-sama, gotong royong pembangunan, pada acara-acara pernikahanadat, acara-acara selamatan (kelahiran anak, panen hasil pertanian) terutama acara gawe adat.

${ }^{10}$ gawe mate masyarakat secara bersama memberikan ta'ziah (hiburan) kepada keluarga yang di tinggal dengan melakukan tahlilan dan atau zikiran, sekaliipun rumah dan tempat tinggal mereka berjauhan dan bahkan berbeda dusun. Kegiatan ini biasanya berlangsung selama 9 hari setelah itu dilanjutkan dengan 40,100 dan 1000 harian. 
system social mereka antara lain; 1) keberadaan perangkat dan fungsi organisasi adat. Bahwa masyarakat Desa Gumantar sangat menghormati struktur dan fungsi adat yang ada. Dalam struktur organisasi adat di Desa Gumantar terdapat beberapa jabatan yaitu, a) Toak Loka'11 b) Penghulu Adat ${ }^{12}$, c) Kyai Adatt ${ }^{13}$, d) Pemekel Adat, ${ }^{14}$ Pemangku, ${ }^{15}$ Turun, ${ }^{16}$ dan Reden. ${ }^{17}$

Kedua dalam hal tata kelola hubungan sosial, masyarakat Desa Gumantar diikat oleh awig-awig sebagai aturan bersama yang bersifat sosial, menyeluruh dan melingkupi berbagai sisi kehidupan; agama, adat, social, dan juga ekonomi. Dalam kaitan dengan kehidupan beragama, awig-awig disusun untuk menjaga dan menjunjung tinggi hari dan atau peristiwa tertentu seperti kesucian bulan ramadhan, maulid adat (kegiatan peringatan milad Nabi pada setiap bulan Rabiul Awwal), Jum'at agung dan untuk mengawal hukum-hukum agama agar tetap dihormati dan dijaga seperti hukum perkawinan, hukuman bagi para pencuri dan juga hal-hal yang menodai hukum sosial. Maka dalam awig-awig nya disepakati untuk tidak melangsungkan pernikahan di bulan puasa. Dalam kehidupan social masyarakat tidak dibolehkan berkelahi, tidak boleh mencuri, membuat keonaran dan lain-lain yang mengancam keamanan dan kenyamanan orang lain. Hal yang sama dalam pelestarian lingkungan, tidak boleh menebang pohon di hutan adat. Maka barang siapa yang menebang pohon akan didenda dengan sapi atau kerbau. Aturan ini berlaku untuk semua kalangan dengan tidak memandang jabatan ataupun keturunan.

\section{Gumantar Pasca Gempa}

Gempa bumi di Lombok, khusus di Desa Gemantar Lombok Utara yang terjadi secara terus menerus telah membawa kerugian yang tidak sedikit bagi masyarakatnya. Selain menelan banyak korban jiwa, juga telah meluluhlantahkan berbagai bangunan rumah, masjid, pertokoan dan sebaginya. Tidak kurang dari 48 orang meninggal, 1050 orang luka-luka, dan tidak kuran 90 persen rumah dan bangunan rusak. ${ }^{18}$ Di samping itu, akses transportasi rusak parah, dan perekonomian masyarakat menjadi lumpuh.

11 Toa' Loka'merupakan jabatan tertinggi dalam tata adat Gumantar. Toa' Loka' ini merupakan jabatan turun menurun dan dari satu garis keturunan. Adapun tugas dari Toak Loka' adalah: 1) mengatur dan mengawasi jabatanjabatan di bawahnya seperti Penghulu, Kyai, Pemekel juga Pemangku, 2) menjaga kelestarian dan terselenggaranya prosesi adat, 3) menjaga dan mengawasi pelaksanaan awiq-awiq adat

12 Penghulu Adat merupakan jabatan dalam adat yang menjadi penanggung jawab dalam bidang agama. Biasanya Penghulu adat bertugas sebagai Juru Doa dalam acara-acara agama seperti roah adat, begawe dn lain-lainnya

13 Istilah Kyai Adat adalah jabatan keagamaan yang menjadi penerima dan penyalur sadakah baik dari masyarakat yang masih hidup maupun sadakah yang diperuntukkan bagi keluarga yang telah meninggal. Jumlah Kyai Adat ini bisa 1 atau 2 dalam satu dusun. Kyai Adat dibagi menjadi 2, yaitu : Kyai Adat Khusus yaitu Kyai Adat yang besifat turun menurun dan mereka tidak mesti orang " taat" ibadah dalam arti menjalankan shalat dan atau jumatan, dan, dan 2) Kyai Adat Biasa yang dipilih dan ditunjuk masyarakat dan tidak mesti satu (1) garis keturunan.

14 Pemekel adat adalah jabatan yang bertugas mengatur tata cara begawe adat. Dalam prosesi perkawinan pemekel ini bertugas sebagai mediator pihak laki-laki dengan pihak perempuan dia juga bertugas menyerahkan dan atau mengantar Pesuke (seserahan berupa uang atau barang kepada pihak perempuan). Dalam acara kematian pemekel juga bertugas menyerahkan sedekah kepada yang berhak yaitu para Kyai yang berperan dalam seluruh proses pengurusan jenazah.

${ }^{15}$ Pemangku merupakan jabatan yang diembankan kepada orang yang ditugasi mengawasi aset adat seperti Tanah Adat dan Hutan Adat. Pemangku juga berfungsi sebagai "pawang" yang mengatur acara di Hutan dan Tanah Adat. Di Desa Gumantar acara bersih hutan dilakukan 3 (tiga) tahun sekali. Pemangku biasanya menggunakan pakaian serba hitam

${ }^{16}$ Turun merupakan jabatan umum di bawah Toak Loka'. Turun dapat dikatakan sebagai asisten toa' loka' dalam mengontrol keselurahan unsure adat

17 Raden merupakan kelompok masyarakat pekerja dan bertugas melaksanakan perintah dari Toak Loka' terutama pada acara-acara adat.

${ }_{18}$ Sumber data berdasarkan hasil observasi dan wawancara dengan kepala Desa Gumantar bapak Jupati pada tanggal 1 September 2018 
Secara fisik maupun psikis gempa Lombok yang terjadi sejak 29 Juli 2018 hingga akhir Agustus 2018 telah menimbulkan kerugian yang sangat besar dan meninggalkan bekas yang mendalam dalam pikiran dan perasaan masyarakat. Laporan dari Badan Nasional Penanggulangan Bencana (BNPB) mencatat bahwa karugian akibat gempa Lombok mencapai 7,45 triliun. Kerusakan dan kerugian yang meliputi sector pemukiman, infrastruktur, ekonomi produktif, sector sosial dan lintas sektor. Adapun angka korban mencapai 515 orang, jumlah luka-luka mencapai 7.145 orang, dan jumlah pengungsi sampai pertengahan Agustus sebanyak 431.416 orang. Adapun rumah rusak mencapai 73.843 unit 798 faslitas umum.

Sebagai desa yang mayoritas wilayahnya berada pada dataran tinggi yang bebukitan. Struktur tanahnya yang bebatuan dan berpasir yang sangatlah labil. Kondisi pemukiman masyarakat yang berada di daerah bebukitan dan tebing menjadikannya rawan terjadi longsor. Bahkan dikatakan oleh Kepala Desa Gumantar bahwa desa ini termasuk salah satu garis api atau pecahan lempeng bumi. Dan menurutnya tidak kurang dari 48 orang meninggal, 1050 orang luka-luka, dan $90 \%$ rumah dan bangunan rusak. ${ }^{19}$

Basri salah seorang tokoh agama sekaligus ketua BPD menceritakan gempa yang terjadi pada hari Minggu tanggal 5 Agustus 2018 yang berkekuatan 7.0 SR sebagai getaran yang sangat dahsyat. Gempa yang diiring gemuruh dan guncangan besar itu terjadi saat sedang berjamaah shalat Isya. Tiba-tiba terjadi suara keras, lampu mati, suara runtuhan rumah-rumah yang hancur, dengan debu yang hitam pekat tidak ada seorang yang saling kenal, semua panik, masingmasing berlarian meninggalkan keluarga, suara takbir, azan, tangisan, dan terikan dimana-mana menambah suasana mencekam. Mereka berlarian ketempat-tempat yang lebih tinggi diiringi rasa ketakutan akan terjadi longsor dan tsunami. ${ }^{20}$ Lebih jauh dikatakan Basri, bahwa gempa ini telah mengakibatkan masyarakat kehilangan anggota keluarga, rumah mereka hancur, binatang ternak (sapi, kambing) ada yang tertimbun dibawah puing-puing reruntuhan kandang, mereka kehilangan harta benda dan harus tinggal di tenda-tenda pengungsian yang sangat dingin di malam hari, dan panas menyengat di siang hari, makan seadanya, dan kekurangan air minum. ${ }^{21}$ Hal senada disampaikan oleh Ust. Hasanul Muttaqin yang mengatakan bahwa gempa bumi di Desa Gumantar tidak saja menyebabkan kehilangan materi, akan tetapi telah menyebabkan keputusasaan, ketakutan, dan kegelisahan serta kesedihan yang sangat tinggi. Masyarakat secara umum mengalami trauma setiap mengingat kejadian tersebut, terlebih ada di antara mereka yang kehilangan anggota keluarga. ${ }^{22}$

Basarnya dampak gempa bagi kehidupan sosial ekonomi masyarakat, telah mendatangkan simpati yang sangat besar dari pemerintah baik pusat maupun daerah. Selain itu berbagai bantuan dan donasi datang dari berbagai unsure baik pribadi, organisasi keagamaan dan lembaga pendidikan. Bahkan Gubernur Jawa Tengah Ganjar Pranowo menurut kepala Desa Gumantar telah bermalam di Gumantar, demikian juga pemerintah daerah kabupaten Seragen

${ }^{19}$ Sumber data berdasarkan hasil observasi dan wawancara dengan kepal Desa Gumantar bapak Jupati pada tanggal 1 September 2018

${ }^{20}$ Basri (tokoh agama dari dusun Dasan Tereng) dalam wawancara tanggal 1 September 2018 di rumahnya.

${ }^{21}$ Ibid

${ }^{22}$ Hasan Muttaqin pimpinan Pondok Pesantren Darul Muttaqin Desa Gumantar wawancara tanggal 1 September 2018 di rumahnya 
Jawa Tengah mulai dari Bupati dan seluruh SKPDnya telah datang berkunjung ke desa Gumantar. Demikian juga dari Universitas Gajah Mada Yogyakarta, Universitas Sebelasmaret Solo ikut serta memberikan bantuan. Para pihak yang membantu desa Gumantar berupa fisik seperti pendirian tenda-tenda, pemasangan pipa air bersih juga mendirikan dapur-dapur umum.

Bantuan berbagai pihak tersebut di atas dapat dirasakan manfaatnya oleh masyarakat terdampak terutama dalam mengatasi persoalan ekonomi, kebutuhan air bersih serta juga kesehatan. Akan tetapi pendekatan-pendeatan pemulihan kejiwaan dengan pendekatan agama tetap mereka butuhkan. Sebagai masyarakat yang berpegang teguh pada nilai-nilai relegiusitas maka siraman rohani cemamah-ceramah keagamaan, pengajian sesuai dengan kondisi yang mereka hadapi tetap menjadi harapan mereka.

\section{Pelaksanaan Kegiatan Trauma Healing Masyarakat Pasca Gempa}

Dari paparan sebelum dapat dipahami bahwa guncangan dahsyat (force majeure) atau gempa yang terjadi dengan intensitas yang sangat tinggi telah mengakibatkan masyarakat kehilangan sandang, pangan dan papan, mereka harus tinggal di tenda-tenda pengungsian yang sangat dingin di malam hari, dan panas menyengat di siang hari, makan seadanya, dan kekurangan air minum. Kehilangan dan kehancuran material akibat guncangan keras tersebut telah memunculkan keputusasaan, ketakutan, dan kegelisahan serta kesedihan yang sangat berkepanjangan. Setiap kali mereka mengingat preistiwa tersebut mereka menangis dan bahka mengeluh mengenang tempat tinggal, bahkan harta benda serta keadaan anggota keluarga yang harus kehilangan nyawa oleh kejadian tersebut.

Berangkat dari kondisi riil atau objektif tersebut dan sesuai dengan harapan yang menjadi focus dampingan ini maka upaya merajut dan menumbuhkan kembali semangat dan jiwa mereka menjadi bagian penting. Ada beberapa asumsi penting yang menjadi argument dampingan yaitu a) perlunya memunculkan rasa kebersamaan dan kepedulian berbagai pihak terhadap kondisi psikis mereka, b) adanya kesadaran masyarakat tentang pentingnya untuk bangkit dari keterpurukan ini, c) pentingnya peranserta tokoh adat dan agama dalam mendorong masyarakat untuk merajut kekuatan adat mereka, dan, d) terciptanyan hubungan harmonis antara perguruan tinggi, pemerintah daerah dan masyarakat.

Kegiatan trauma healing ini berlangsung pada hari Sabtu tanggal 15 September 2018 bertempat di Runtuhan Masjid Nurul Muttaqin Dusun Gumantar Desa Gumantar Kecamatan Kayangan Lombok Utara. Kegiatan yang berlangsung mulai pukul 08.00 wita tersebut dihadiri oleh 60 orang peserta yang terdiri dari 30 orang laki-laki dan 30 orang perempuan. Para peserta merupakan warga desa Gumantar yang merasakan gunjangan gempa dan menghancurkan dusun-dusun mereka. Di antara mereka hadir adalah Kepala Desa Gumantar dan Ust. Basri tokoh agama dan masyarakat. Sedangkan narasumber utama, yaitu, 1) Prof. Dr.TgH. Masnun Thahir, M.Ag Guru Besar Filsafat Hukum Islam UIN Mataram sekaligus dan Dr. Faizah, MA Dosen Psikologi Dakwah UIN Mataram, dan 3) Japarti Kepala Desa Gumantar Kecamatan Kayanga Lombok Utara.

Trauma Healing masyarakat diawali dengan paparan tentang tujuan dari kegiatan ini oleh Dr. H. Subhan Abdullah Acim, MA selaku ketua pengabdi yang dipandu oleh Muhammad 
Sa'i, Masebagai tim pengabdi. Dr. H. Subhan Abdullah, MA mengawali pengantarnya dengan menyampaikan rasa simpati dan belasungkawa atas meninggalnya sebagai dari anggota keluarga. Gempa bumi ini memang dirasakan di seluruh pulau Lombok dan tentu yang terparah adalah Lombok Utara. Namun demikian bencana ini tidak perlu disesali dan menjadikan berputus semangat, tetapi semua harus yakin dan sadar ini merupakan sunnah Allah yang ditetapkan di alam raya ini. Secara ilmiah kejadian ini tidak dapat dipastikan kapan waktunya.

Kepala Desa Gumantar Bapak Japarti yang memberikan informasi dan penjelasan tentang potensi dan kekuatan selanjutnya memberikan apresiasi dan penghargaan yang tinggi serta ucapan terima kasih atas terselenggaranya kegiatan ini. Masyarakat Desa Gumantar sedang syok dan dalam tekanan jiwa akibat gempa yang terus menerus terjadi. Desa Gumantar yang dihuni oleh 6.219 jiwa yang terdiri dari 3.122 jiwa laki-laki, dan 3.097 perempuan, serta 1.982 kepala keluarga adalah desa terparah. Di desa ini lebih dari tidak kurang dari 48 orang meninggal, 1050 orang luka-luka, dan $90 \%$ rumah dan bangunan rusak.

Secara fisik Japarti menyampaikan bahwa desa yang dipimpinnya telah mendapatkan perhatian yang sangat besar dari berbagai pihak baik pemerintah pusat, daerah maupun beberpa perguruan tinggi. Di antara bantuan dari luar daerah selain dari pusat berasal dari Gubernur Jawa Tengah, Bupati dan SKPD Kabupaten Sragen Jawa Tengah, di UGM, UNS dan organisasi-organisasi sosial lainnya. Bantuan-bantuan tersebut dalam bentuk fisik seperi penyediaan tenda, sekolah darurat, pipa air bersih, serta kebutuhan makanan dan pakaian. Karena ini menyampaikan ucapan terima kasih untuk semua itu.

Selanjutnya Prof. Dr. Masnun Thahir, M.Ag.sebagai motivator/pemateri mengajak dan merenung sejenak, seraya bersyukur betapa besar rahmat dan nikmat Allah dalam diri kita. Lebih jauh dikatakan, bahwa bencana ini adalah bala' atau bencana yang memang Allah tekdirkan di alam ini, tidak ada yang bisa melawannya dan ini murni atas kudrah dan iradah Allah atas segala ciptaan Nya. Ini tentu berbeda dengan musibah yang merupakan bencana yang disebabkan oleh tindakan dan prilaku manusia. Karena itulah menyikapi bala'yang Allah takdirkan melalui gempa disikapi dengan do'a dan kesabaran. La haula wala quwwata illa billahi al-'aliy al-'azim/ tidak ada daya dan kekuatan kecuali atas kehendah Allah yang Maha Tinggi dan Maha Agung.

Dalam menyikapi bala' yang melanda pulau seribu masjid perlu;

a) merengungi ikrar dalam iftitah shalat inna shalati wa nusuki wa mahya yaw a ma ma ti lillahi rabil alamin" sesungguhnya shalat, ibadah, hidup dan matiku karena Allah Tuhan semesta alam.

b) Mengikrarkan kekecilan dan kelemahan dihadapan san Khalq Allah Swt "La haula wala quwwata illa billahi al-'aliy al-'azim/ tidak ada daya dan kekuatan kecuali atas kehendah Allah yang Maha Tinggi dan Maha

c) Bangkit dan sadar dari kondisi syok, seraya mengajar jamaah untuk bertasbih, bertahmid, dan bertahlil ". Dengan "tasbih, tahmid, tahlil dan takbir" secara berjamaah beberapa diantara mereka sentak mencucurkan air mata, Prof. Masnun mengajak jamaah, mari menangis, mari bersedih tapi mari juga kita sadar untuk apa kita menangis dan untuk apa terus bersedih, semua sudah terjadi, sehingga mari kita bangkit bersama. Demikian, 
Prof. Masnun terus memotivasi dan mengajak merenung yang selingi permainan, dan mengajak mereka untuk mulai senyum dan bergembira.

Setelah shalat zuhur dan makan siang dilanajutkan dengan pemberian santunan dan penyajian materi oleh Dr. Faizah, MA. Pertama -tama Dr. Faizah, MA meyampaikan simpati terhadap shahib al-mushab/orang yang tertimpa musibah. Selanjutnya peserta dikelompokkan menjadi 2 kelompok. Para peserta menyampaikan pengalaman saat gempa dan perasaan yang dirasakan setelah gempa tersebut. Beberapa peserta bahkan ada yang menangis dan histeris ketika mingingatkan kejadian yang menimpanya.

Dr. Faizah, MA kemudian mengungkapkan bahwa menghadapi bencana/ al-bala' seperti ini, tidak ada yang tidak takut, tidak ada yang tidak bersedih, khawatir dan bahka putus asa, semua mengalami kepanikan yang sama, tidur tenda-tenda, di tanah-tanah lapang, di depandepan rumah, dengan ketakutan yang sama, terlebih bermunculannya isu-isu lain, ada gempa susulan yang lebih besar, ada tsunami, kasus pencurian, hingga phenomena telapak tangan dan lain sebagainya,...menambah rasa tidak tenang.

Sungguh apapun yang sedang menimpa, hendaknya dinyakini sebagai kejadian di luar batas kemampuan dan jangkauan akal sehat. Tapi sebagai orang beriman mari kita sadari "at bald" atau ujian besar yang Allah turun tidak selalu berupa sesuatu " al-syar" yang mengerikan, yang menakutkan, akan tetapi bisa dalam bentuk " al-khaer" sesuatu yang menyenangkan, menggembirakan " wa lanablu kum bi al-syarr waal-khaer firnah" sungguh Kami uji kamu sekalian dengan sesuatu yang tidak baik (yang mengerikan, yang menakutkan) dan sesuatu yang baik (yang menyenangkan, menggembirakan) sebagai sebuah cobaan. Bahkan Allah nyatakan bahwa ujian dan cobaan yang ditimpakan kepada manusia bertujuan untuk menunjukkan siapa yang bisa berjuang menghadapi dan bangkit kembali dan orang yang memiliki pertahanan jiwa" wa lanabluwannakum hatta na'lama al-mujahidina minkum waal-shabirin.. /sesungguhnya kami benar-benar menguji kamu agar kami mengetahui orangorang yang berjihad di antara kamu dan orang-orang yang bersabar.

Di tengah-tengah kepanikan, dan ketakutana yang menimpa maka kendaknya lebih banyak bemunajat, berzikir, sebab, dalam pandangan Islam- al-Qur'an- berzikir merupakan cara paling ampuh untuk meraih ketenangan jiwa ". Di akhir dari paparannya, pemateri kembali mengajak seluruh peserta untuk berbicara dengan diri sendiri, seraya merenung, bahwa kehidupan dan segala yang melekat pada diri sebagai amanah dan titipan Tuhan. Maka dalam mengahadapi peristiwa yang telah terjadi dengan memperbanyak sekap pengakuan tentang keagungan Allah dan kelemahan diri manusia.

\section{Kesimpulan}

1. Gempa bumi yang mengguncang pulau seribu masjid dan lebih khusus Desa Gumantar Kecamatan Kayangan Lombok Utara yang terjadi terus menerus telah memporakporandakan bangunan-bangunan rumah, perkantoran dan masjid-masjid serta fasilitas umum lainnya seperti sarana transportasi, air bersih dan sumber perekonomian masyarakat bahkan menelan sejumlah jiwa.Terdapat hubungan vararel yang saling kait 
mengkait antara kerusakan fisik-material dengan masalah psikis. Kerusakan berbagai sarana dan prasaran serta meninggalnya sebagai anggota keluarga telah menimbulkan trauma yang mendalam.

2. Pesca gempa masyarakat Desa Gumantar mengalami keputusasaan, ketakutan, dan kegelisahan serta kesedihan yang sangat tinggi setiap mengingat peristiwa yang menimpa mereka.

3. Penanganan masalah sosial pasca gempa atau trauma healing dengan metode dan pendekatan dakwah keagamaislaman sangat tepat. Penguatan hati melalui bacaan-bacaan kalimah al-tahyyibah (tasbih, tahmid dan tahlï) dengan bimbingan mursyid (guru ) yang kompeten sangat relevan. Selain itu kerjasama berbagai pihak menjadi bagian yang tidak dapat dipungkiri adanya.

\section{Referensi}

Aliyudin \&Enjang A.S. Dasar-Dasar IImu Dakwah: Pendekatan Filosofis Dan Praktis. Bandung: Widya Padjadjaran, 2009

Amien, M. Rais, Cakrawala Islam; Antara Cita dan Fakta, (Bandung: Mizan, 1992

Anshari E.S., Pokok-Pokok Pikiran Tentang Islam, (Jakarta: Usaha Enterpress, 1976

Audah, Ali, Konkordansi al-Qur'an Panduan Kata Dalam Mencari ayat al-Qur'an (Jakarta : PT. Pustaka Litera AntarNusa, 1997

Arifin H.M.M. Ed., Psikologi Dakwah, (Jakarta: Bumi Aksara, 1993

Bukhari. B, Makalah Pelatihan Trauma Healing bagi Mahasiwa Fakultas Dakwah dan Komunikasi IAIN Walisongo Semarang 2014

Faidullah al-Husain al-Muqaddisi, Fath al-Rahman li al-Thalib ayat al-Qur'an, (Bairut: Dar al-Fikr, t.th)

Kristinawati Tampubolon, Pengertian Trauma Healing, https://www.scribd.com diakses Agustus 2018

Latipun, Psikologi Konseling, (Malang: UMM Press, 2000)

Manzur, Ibnu, Lisan al-Arab, (Bairut: Dar Ihya al-Turats al-'Araby, t.th)

Muhyiddin A. \& Safei A.A., Metode Pengembangan Dakwah, (Bandung: Pustaka Setia 2002

Pusdiklat PMI Jawa Tengah, Materi Pelatihan Dukungan Psikososial PMI Daerah Jawa Tengah (Salatiga: PMI Jawa Tengah 2006)

Quraisy M. Shihab, Membumikan Al-Qur'ân, (Bandung: Mizan, 1996

TIM Penyusun Kamus, Kamus Besar Bahasa Indonesia Departemen Pendidikan dan Kebudayaan cet. Ke X ( Jakarta : Balai Pustaka, 1999)

Yahya, Toha Omar, IImu Dakwah, (Jakarta: Wijaya, 1971), h.1 